\title{
Studies on mangrove diversity of India with special reference to Lothain island wildlife sanctuary
}

\author{
Goutam Brahma $^{1}$ and Sobhan Kumar Mukherjee ${ }^{2}$ \\ ${ }^{1}$ Bill Joypur High School, Howrah 711205, , West Bengal, India \\ ${ }^{2}$ University of Kalyani, Kalyani 741235, Nadia, West Bengal, India
}

\section{Article history}

Received: 8 January 2016

Accepted: 12 January 2016

Published online: 18 January 2016

(C) Brahma and Mukherjee (2016)

Editor

K. K. Sabu

\section{Publisher}

Horizon e-Publishing Group

Corresponding Author

Goutam Brahma

$凶$ goutam.bsi@gmail.com

\begin{abstract}
Mangroves are extremely important bio-resources that are crucial to coastal environment. Indian mangrove vegetation covers about 6,756 sq. km. Along the 7516.6 $\mathrm{km}$ long coast line, including island territories. Estimates of the number of species considered, mangroves in the world ranges from 50-90, and in India from 50-60. Mangroves are declining rapidly as they are getting degraded for agriculture, aquaculture, tourism, urban development and over exploitation. India lost $40 \%$ of its mangrove area during the last century. The present work is focused on assessing the status of mangrove area in India with special reference to the Lothian Island Wildlife Sanctuary in Sundarbans. Total 30 species were collected during the field visits. Among them 16 species are major mangroves and 14 are mangrove associates. Effective governance structures, better planning for rehabilitation of degraded mangroves, education and awareness building in local communities are needed to conserve, protect and restore the valuable mangrove wetland ecosystems.
\end{abstract}

\section{Keywords}

Mangrove; wildlife sanctuary; succession; zonation

Brahma, G. and Mukherjee, S. K. 2016. Studies on mangrove diversity of India with special reference to Lothain island wildlife sanctuary. Plant Science Today 3(1): 25-29. http://dx.doi.org/10.14719/pst.2016.3.1.186

\section{Introduction}

Mangroves represent the most unique forest ecosystem, situated at the interface between land and the sea of tropical and subtropical latitudes. It supports genetically diverse groups of aquatic and terrestrial organisms. As the mangrove environment includes diversified macro habitats such as forests, litter floor, mudflats, water bodies, coral reefs and sea grass ecosystem, there is a remarkable coverage of biodiversity which is still not fully explored and needs full documentation.

\section{World Status of Mangroves}

Mangroves are distributed in about 112 countries of the world in the tropical and subtropical zones, covering a total area of about 18 million hectares.
Mangroves are mainly found between $32^{\circ} \mathrm{N}$ and $38^{\circ}$ $S$ latitudes along the tropical coast of Africa, Australia, Asia and Americas (Table 1).

The Old World Tropics (Indo-West Pacific regions) is the most important in respect of abundance of several true mangrove species and richness of mangrove zones (Finlayson and Moser, 1991). Mangroves and their associated flora grow best in the areas where the existing adequate rain fall is ranging from $1000 \mathrm{~mm}$ to $3000 \mathrm{~mm} /$ year with high atmospheric humidity (Anon., 1978). Out of the total area of world mangroves, $414.4 \%$ exist in South and South-east Asia, followed by the Americas (27.1\%). The Indo-West Pacific mangroves or the old World mangroves are estimated to be spread over an area of about 1,02,631 sq km and 
Table 1. Areal coverage of Mangrove Forests (Spalding, 1997)

\begin{tabular}{llc}
\hline Sl. No. & \multicolumn{1}{c}{ Region } & $\begin{array}{c}\text { Area in sq. } \mathbf{~ k m . ~} \\
\text { (\% of Total Area) }\end{array}$ \\
\hline 1. & South and South-East Asia & $75,170(41.4 \%)$ \\
\hline 2. & The Americas & $49,096(27.1 \%)$ \\
\hline 3. & West Africa & $27,995(15.4 \%)$ \\
\hline 4. & Australia & $18,788(10.4 \%)$ \\
\hline 5. & East Africa \& Middle East & $10,348(5.7 \%)$ \\
\hline
\end{tabular}

Table 2. Indian Mangrove Areas (Anon., 1987)

\begin{tabular}{|c|c|c|}
\hline Sl. No. & Region & $\begin{array}{c}\text { Area in sq. km. } \\
\text { *(\% of Total Area) }\end{array}$ \\
\hline \multicolumn{3}{|c|}{ East Coast } \\
\hline 1. & Sundarbans & $4200(62.2 \%)$ \\
\hline 2. & Orissa Coast/ Mahanadi Delta & $150(2.2 \%)$ \\
\hline 3. & Andhra Pradesh Coast & $200(3 \%)$ \\
\hline 4. & Tamil Nadu Coast & $150(2.2 \%)$ \\
\hline 5. & Andaman and Nicobar & $1190(17.7 \%)$ \\
\hline \multicolumn{3}{|c|}{ West Coast } \\
\hline 6. & Kerala Coast & $16(0.2 \%)$ \\
\hline 7. & Karnataka Coast & $60(0.9 \%)$ \\
\hline 8. & Goa Coast & $200(3 \%)$ \\
\hline 9. & Maharashtra Coast & $330(4.9 \%)$ \\
\hline 10. & Gujrat Coast & $260(3.8 \%)$ \\
\hline 11. & Lakshadwip/ Minicoy & 0.25 \\
\hline
\end{tabular}

(*Calculated considering the total area of both East and West Coast)

the New World mangroves over an area of about 71,029 sq km (Macintosh, 1984; UNESCO, 1984).

Indonesia and Brazil shows the highest mangrove cover area of about 25,000 sq $\mathrm{km}$. The next dominant mangrove area is in the Australia covering about $11,620 \mathrm{sq} \mathrm{km}$ Mangrove areas in Brazil and Australia are more than Sundarbans. However, these mangrove zones are scattered and the mangrove species diversity is less than that of the Sundarbans mangals. The undivided Sundarbans in India and Bangladesh with a total area of about $10,000 \mathrm{sq} \mathrm{km}$ is the largest continuous mangrove patch. This is the only 'mangrove habitat tiger land' in the world.

\section{Indian Mangroves}

In India, the mangroves are mainly restricted in patches in both the east and west coasts and in Andaman and Nicobar islands. The total mangrove area in India is reported as 6,756 sq $\mathrm{km}$, out of which 5,890 sq $\mathrm{km}$ is in the East Coast and 866.25 sq km under West Coast (Anon., 1987) (Table 2).

Mangroves are wide spread on the East Coast of India due to nutrient rich alluvial soil formed by 6 major rivers- Ganges, Brahmaputra, Mahanadi, Godavari, Krishna and Cauvery. All these rivers have flow of freshwater along their deltaic coasts (Gopal and Krishnamurthy, 1993). Moreover, the smooth gradual sloping in the East Coast provides a large span of area for successful colonization of mangroves (Untawale, 1986).

Three different types of mangrove habitats, namely deltaic, backwater-estuarine and insular are dominant in India (Kathiresan and Qasim, 2005). Besides the three types of mangrove habitats, the Indian mangroves are again classified based on their spatial and temporal variations of environmental factors (Selvam, 2003). The categories are- (i) tide-dominated as in Sundarbans and Mahanadi mangroves; (ii) river-dominated as in Godavari, Krishna, Pichavaram and Muthupet mangroves and (iii) drowned river valley type for Gujarat mangroves.

\section{Mangroves of Indian Sundarbans}

The Sundarbans is the largest contiguous mangrove patch in the world formed at the estuarine mouth of the Ganga-Brahmaputra river system, both in India and Bangladesh. It occupies the lower part of the Bengal Basin. This is the only mangrove-tiger land on the globe, where the world famous 'Royal Bengal Tiger' still lives. Sundarbans mangrove forest area in Bangladesh is estimated to be about $66 \%$, while Indian Sundarbans covers an area of about $34 \%$ of the total (Naskar and Mandal, 1999).

Three centuries back, the total forests and river area in undivided Sundarbans, of present day's 
Table 3. Major mangroves collected during the quadrate study

\begin{tabular}{|c|c|c|c|}
\hline Sl. No. & Scientific Name & Family & Local Name \\
\hline 1 & Acrostichum aureum L. & Adiantaceae & Hudo \\
\hline 2 & Aegialitis rotundifolia $\mathrm{Roxb}$. & Plumbaginaceae & Tora \\
\hline 3 & Aegiceras corniculatum (L.) Blanco & Myrsinaceae & Khalsi \\
\hline 4 & Avicennia alba Blume & Avicenniaceae & Kalo Baine \\
\hline 5 & Avicennia marina (Forssk.) Vierh. & Avicenniaceae & Peyara Baine \\
\hline 6 & Avicennia officinalis L. & Avicenniaceae & Jat Baine \\
\hline 7 & Bruguiera gymnorrhiza (L.) Lam. & Rhizophoraceae & Kankra \\
\hline 8 & Bruguiera parviflora (Roxb.) Wight. \& Arn. ex Griff. & Rhizophoraceae & Bon Bakul \\
\hline 9 & Ceriops decandra (Griff.) Ding. Hou. & Rhizophoraceae & Jat Goran \\
\hline 10 & Ceriops tagal (Perr.) C.B. Robins. & Rhizophoraceae & Mat Goran \\
\hline 11 & Excoecaria agallocha L. & Euphorbiaceae & Gnewa \\
\hline 12 & Nypa fruticans Wurmb. & Arecaceae & Golpata \\
\hline 13 & Phoenix paludosa Roxb. & Arecaceae & Hental \\
\hline 14 & Rhizophora apiculata Blume & Rhizophoraceae & Garjan \\
\hline 15 & Sonneratia apetala Buch.-Ham. & Sonneratiaceae & TakKeora \\
\hline 16 & Xylocarpus mekongensis Pierre & Meliaceae & Pussur \\
\hline
\end{tabular}

India and Bangladesh, was more than 20,000 sq $\mathrm{km}$ and restricted within $21^{\circ} \mathrm{N}$ to $22^{\circ} 31^{\prime} \mathrm{N}$ latitude and $88^{\circ} 10^{\prime} \mathrm{E}$ to $92^{\circ} 15^{\prime} \mathrm{E}$ longitude. During partition of Bengal (1947), more than $66 \%$ of the total mangrove forest of Sundarbans had fallen within the jurisdiction of Bangladesh and only $34 \%$ remained within India, between $21^{\circ} 31^{\prime} \mathrm{N}$ to $22^{\circ} 30^{\prime}$ $\mathrm{N}$ latitude and $88^{\circ} 10^{\prime} \mathrm{E}$ to $89^{\circ} 51^{\prime} \mathrm{E}$ longitude. Geographical location of Sundarbans lies southeast of Kolkata and forms the part of Gangetic Delta which borders on the Bay of Bengal (Morgan and McIntire, 1959).

Indian Sundarbans was declared as a biosphere reserve in the year 1989. This Biosphere Reserve supports 4266.66 sq. $\mathrm{km}(66 \%)$ area out of a total $6419 \mathrm{sq} \mathrm{km}$ mangrove cover area in India (Naskar, 2004). Considering the importance and uniqueness, the Sundarbans has been accepted in the Global Network of Biosphere Reserves by UNESCO in 2001. The mangrove forest of Sundarbans was also declared as a 'World Heritage Site' and 'Ramsar Wetland Site' for proper preservation of its flora and fauna.

Sunderban Biosphere Reserve in India covers a total area of 9,630 sq km, of which an area of about $1,692 \mathrm{sq} \mathrm{km}$ is designated as core zone and an area of 2,233 sq km as buffer zone. The buffer zone includes three (3) Wildlife Sanctuaries namely Sajinakhali (362 sq km), Lothian Island (38 sq km) and Haliday Island (6 sq km).

\section{Area of Study}

Lothian Island is the second largest Wildlife Sancturay located in Indian Sundarbans. This island covering an area $38 \mathrm{sq} \mathrm{km}$ was notified as Sanctuary in 1948 and re-notified through notification number 5392- For dated $24^{\text {th }}$ June,
1976. Considering the existence of unique flora and fauna of the Sundarban- the Lothian Island was declared as Wildlife Sanctuary in the year 1976. It is situated at the confluence of river Saptamukhi and the Bay of Bengal. In the northern part of the island, the ground level is high, while in the northern part land is low.

\section{Materials and Methods}

The study was conducted only in the mangrove forest area not in the reclaimed lands. Survey was undertaken in the reserved forests areas of Lothian Island Wildlife Sanctuary of Sundarban Biosphere Reserve.

The survey for floristic data collection was conducted with the help of mechanical boats, launches and on foot wherever possible. Since the canopy height is low, the visibility was magnified using binoculars. The small creeks were studied with smaller hand driven country boats.

\section{Results and Discussion}

Total 30 species were collected during the field visits. Among them 16 species are major mangroves (Table 3) and 14 are mangrove associates (Table 4). They belong to 23 families.

Zonation of plant communities in intertidal habitats is particularly striking and often results in monospecific bands of vegetation occurring parallel to the shoreline. Although zonation patterns are usually depicted in a manner that suggests a rigid sequence proceeding from the shoreline to upland regions, many patterns resemble a mosaic with vegetational patterns occurring repeatedly where the land mass is interrupted by watercourses or other variations in 
Table 4. Mangroves associates collected during the quadrate study

\begin{tabular}{clll}
\hline Sl. No. & Scientific Name & Family & Local Name \\
\hline 1 & Acanthus ilicifolius L. & Acanthaceae & Hargoja \\
\hline 2 & Caesalpinia bonduc (L.) Roxb. & Caesalpiniaceae & Natakaranja \\
\hline 3 & Caesalpinia crista L. & Caesalpiniaceae & ShingrLata \\
\hline 4 & Clerodendrum inerme (L.) Gaertn. & Lamiaceae & Banjui \\
\hline 5 & Derris scandens (Roxb.) Benth. & Fabaceae & Noa lata \\
\hline 6 & Derris trifoliata Lour. & Fabaceae & Panlata \\
\hline 7 & Dalbergia horrida (Dennst.) Mabb. & Fabaceae & Chulia Kanta \\
\hline 8 & Heliotropium curassavicum L. & Boraginaceae & Hatisur \\
\hline 9 & Ipomoea pes-caprae (L.) R. Br. & Convolvulaceae & Chhagal Knuri \\
\hline 10 & Phragmites vallatoria (Pluk. ex L.) Veldkamp & Poaceae & Nalkhagra \\
\hline 11 & Porteresia coarctata (Roxb.) Tateoka & Poaceae & Dhani Ghas \\
\hline 12 & Suaeda maritima (L.) Dum & Chenopodiaceae & Giria sak \\
\hline 13 & Suaeda nudiflora (Willd.) Moq. & Chenopodiaceae & Giria sak \\
\hline 14 & Thespesia populnea (L.) Soland ex Correa & Malvaceae & Parespipal
\end{tabular}

\section{Porteresia coarctata}

\section{Acanthus ilicifolius, Avicennia spp}

\section{Suada maritima, S. nudiflora}

\section{Excoecaria agallocha, Aegiceras corniculatum, Aegialitis rotundifolia}

\section{Bruguiera gymnorrhiza, Ceriops decandra, Rhizophora apiculata, Avicennia officinalis}

\section{Xylocarpus mekongensis}

\section{Phoenix paludosa}

Fig. 1. Flow chart showing the succession pattern of Lothian Island

topography. The large variation in floristic composition of mangrove communities means that patterns of species distribution across the intertidal zone will vary substantially among geographic regions. 


\section{Plant Succession Pattern in Lothian Island:}

A well marked succession pattern of mangroves in newly silted char-lands is observed during the field work. Succession is observed with the first appearance of Porteresia coarctata in newly formed stable lands, followed by the appearance of Avicennia marina, A. alba and Acanthus ilicifolius. A flow chart is presented to understand the succession pattern (Fig. 1). Zonation patterns in mangrove forests may also vary on a local scale. Occurrence of species may differ across an estuary, apparently in response to differences in freshwater input. For example, species found at the seaward end of the estuary may be absent from the headwaters. Although zonation typically refers to patterns created by segregation of different species, differences in stature and productivity of plants across environmental gradients may also result in readily discernible patterns. Zones may be comprised of different architectural forms that represent variations in height and vigour.

\section{Acknowledgements}

The first author is grateful to Dr. H.S. Debnath (former H.O.O. And Scientist 'E', Acharya Jagadish Chandra Bose Indian Botanic Garden, Botanical Survey of India), for his valuable suggestions and supervision. The authors would like to thank West Bengal Forest Department, DFO South 24-Parganas for giving their permission to undertake the study and for providing forest guards.

\section{References}

Anonymous, 1978. Report of the UNESCO. Regional Seminar held in Dacca, Bangladesh.

Anonymous, 1987. Mangroves in India- Status Report. Government of India, Ministry of Environment and Forests, New Delhi.

Gopal, B. and Krishnamurty, K. 1993. Wetlands of South Asia. In: Whigham, D.F., Dy Kyjova, D. and Hejny, S. (eds.), "Wetlands of the World": Kluwer Academic Publishers, Netherlands. pp. 345-414. doi:10.1007/978-94-015-8212-4_10

Kathiresan, K. and Qasim, S.Z. 2005. Biodiversity of Mangrove Ecosystems. Hindustan Publishing Corporation (India), New Delhi.

Macintosh, D.J. 1984. Ecology and productivity of Malaysian mangrove crab population. In: Soepadmo, E., Rao, A.N. and Macintosh, D.J. (eds.), Proceeding Asian Symposium on "Mangrove Environment and Research Management" University of Malaya, Kualalampur, Malaysia. Pp. 354-377.

Morgan, J.P. and McIntire, W.G. 1959. Quaternary Geology of the Bengal Basin, East Pakistan and Burma. Bull Geol. Soc. Am. 70: 319-342. doi: 10.1130/0016-7606(1959)70[319:QGOTBB]2.0.CO;2

Naskar, K.R. 2004. Manual of Indian Mangroves. Daya Publishing House, Delhi.

Naskar, K.R. and Mandal, R.N. 1999. Ecology and Biodiversity of Indian Mangroves. 2 vols. Daya Publishing House, Delhi.
Selvam, V. 2003. Environmental classification of mangrove wetlands of India. Curr. Sci. 84 (6): 757765.

Spalding, M. 1997. The global distribution and status of mangrove ecosystems. International News Letter of Coastal Management- Intercoast Network. Special edition 1: 20-21.

UNESCO, 1984. Handbook of Mangrove Area Management. Edited by Lawrence, S. Hamilton and Snedaker, S.C.

Untawale, A.G. 1986. Hoe to Grow Mangroves? A field guide. Prepared by NIO, Dona Paula, Goa, WWF for Nature, Bombay, India (2 ${ }^{\text {nd }}$ Edition). pp. 1-9. 